\title{
ANALISIS PSIKOLOGI DAN NILAI PENDIDIKAN KARAKTER DALAM NOVEL MATA DI TANAH MELUS SERTA PEMANFATAANNYA DALAM PEMBELAJARAN SASTRA
}

\author{
Ainidya Marhaenita Kinanti, Andayani, Suyitno \\ Universitas Sebelas Maret \\ Email: ainidyamarhaen@gmail.com
}

\begin{abstract}
Abstrak: Penelitian ini bertujuan untuk mendeskripsikan dan menjelaskan (1) struktur novel Mata di Tanah Melus karya Okky Madasari; (2) aspek kejiwaan tokoh utama dalam novel Mata di Tanah Melus karya Okky Madasari berdasarkan teori kebutuhan bertingkat Abraham Maslow; (3) nilai-nilai pendidikan karakter dalam novel Mata di Tanah Melus karya Okky Madasari; (4) relevansi kajian psikologi sastra novel Mata di Tanah Melus dengan pembelajaran sastra di sekolah menengah pertama. Penelitian ini menggunakan metode deskriptif kualitatif dengan pendekatan psikologi sastra untuk mendeskripsikan aspek kejiwaan tokoh utama dalam novel. Sumber data penelitian ini adalah novel Mata di Tanah Melus karya Okky Madasari yang diterbitkan Gramedia Pustaka Utama. Teknik pengumpulan data yang digunakan yaitu analisis dokumen dan wawancara. Validasi data yang digunakan yaitu triangulasi sumber data. Hasil penelitian sebagai berikut: (1) struktur novel yang terdapat dalam novel Mata di Tanah Melus antara lain tema, tokoh dan penokohan, alur, latar; (2) kebutuhan bertingkat yang sudah dipenuhi dengan baik oleh tokoh utama yaitu kebutuhan fisiologis. Kebutuhan rasa aman, kebutuhan dicintai dan memiliki, kebutuhan penghargaan tokoh Matara belum tercukupi dengan baik. Kebutuhan aktualisasi diri belum dapat tercapai karena kebutuhan di tingkat yang lebih rendah belum tercukupi; (3) nilai pendidikan karakter yang paling dominan dalam novel ini yaitu rasa ingin tahu. Karakter tersebut tercermin dari perilaku Matara yang selalu ingin tahu tentang sejarah dan budaya Belu; (4) Novel ini dapat direlevansikan dengan materi pembelajaran sastra di SMP.
\end{abstract}

Kata kunci: psikologi sastra, teori Abraham Maslow, novel Mata di Tanah Melus, pembelajaran sastra

\section{PSYCHOLOGICAL AND CHARACTER EDUCATION VALUE ANALYSIS IN “MATA DI TANAH MELUS” NOVEL AND ITS UTILIZATION IN LITERATURE LEARNING}

\begin{abstract}
The objectives of this research are to describe and explain (1) the structure of novel Mata di Tanah Melus by Okky Madasari; (2) the psychological aspects of main character in the novel based on human needs' theory by Abraham Maslow; (3) the value of education character in the novel Mata di Tanah Melus; (4) to describe relevance in the novel with literature learning in the junior high school. This research used a qualitative descriptive method in psychology literature to describe psychological aspects of the main character. The data source of this research is the novel entitled Mata di Tanah Melus by Okky Madasari publised Gramedia Pustaka Utama. The validaty data used the triangulation data source. The results show that (1) the novel structures are theme, character and characterization, plot, and setting; (2) the psychplogical aspect of main character based of human needs' theory are included; a physiological needs, the needs of savety, love and belonging, esteem of Matara are not fulfill well; (3) the most dominant value of caracter education is curiosity; (4) the relevance of the novel with literature learning in the junior high school based on the results of interviews.
\end{abstract}

Keywords: psychology literature, Abraham Maslow theory, the novel Mata di Tanah Melus, literature learning

BASASTRA Jurnal Bahasa, Sastra, dan Pengajarannya

Volume 8 Nomor 1, April 2020, P-ISSN 2302-6405, E-ISSN 2714-9765 


\section{PENDAHULUAN}

Karya sastra adalah produk karangan manusia yang mencerminkan perilaku dan perasaan manusia. Cerminan tersebut dapat dinikmati dalam beberapa bentuk, yakni prosa, puisi, dan drama. Sastra sebagai sebuah karya memiliki nilai estetis dan etis atau dikenal dengan istilah dulce et utile. Istilah tersebut diartikan bahwa sastra tidak hanya berfungsi untuk menghibur tetapi juga berfungsi untuk pembelajaran. Wellek dan Warren menjelaskan beberapa fungsi sastra, yakni (a) sebagai hiburan; (b) sebagai renungan; (c) sebagai bahasan pelajaran; (d) sebagai media komunikasi simbolik; (e) sebagai pembuka paradigma berpikir (Emzir dan Rohman, 2015: 9).

Bertolak pada fungsi-fungsi sastra yang telah dijelaskan, sastra bermanfaat di bidang pendidikan. Di Indonesia, sastra menjadi salah satu materi pembelajaran pada mata pelajaran Bahasa Indonesia, baik di jenjang SMA maupun SMP. Objek kajian sastra di Kurikulum 2013 SMP beragam, salah satunya yaitu novel. Kajian tentang novel terdapat dalam Kompetensi Dasar SMP kelas VIII yang membahas struktur dan kebahasaan dalam novel.

Novel merupakan salah satu bentuk karya sastra yang menceritakan permasalahan kehidupan di masyarakat secara kompleks dan utuh. Hal ini sesuai dengan pernyataan yang dikemukakan oleh Stanton (2012: 90), novel menghadirkan karakter yang lebih banyak dan kompleks. Ceritanya tersaji dalam beberapa kurun waktu mengikuti alur. Rangkaian peristiwa berpindah ditandai adanya perubahan latar tempat, waktu ataupun perubahan karakterkarakter

Berkaitan dengan hal di atas, pemilihan novel Mata di Tanah Melus karya Okky Madasari sebagai objek kajian pada penelitian ini dikarenakan isi atau materi dalam novel. Novel tersebut sangat menarik jika dilihat dari aspek kejiwaan tokoh utama yang masih berusia dua belas tahun dan segala pemikiran anak usia tersebut menghadapi permasalahan yang ada. Pendekatan psikologi sastra dipilih untuk mengkaji novel Mata di Tanah Melus karena mampu mengungkapkan kejiwaan tokoh dan perwatakan tokoh. Nilai-nilai pendidikan karakter juga dikaji dalam novel Mata di Tanah Melus untuk pertimbangan relevansi novel ini dengan pembelajaran sastra di sekolah menengah pertama. Usia tokoh dalam novel tidak jauh berbeda dengan usia siswa SMP sehingga perkembangan kejiwaan dimungkinkan sama. Adapun aspek kejiwaan tokoh dikaji menggunakan teori kebutuhan bertingkat Abraham Maslow.

Pedekatan psikologi sastra memiliki peranan penting dalam pemahaman sastra karena adanya beberapa kelebihan seperti: pertama, pentingnya psikologi sastra untuk mengkaji lebih mendalam aspek perwatakan; kedua, dengan pendekatan ini dapat memberi umpan balik kepada peneliti tentang masalah perwatakan yang dikembangkan; dan terakhir, penelitian semacam ini sangat membantu untuk menganalisis karya sastra yang penuh dengan masalah-masalah psikologis (Endaswara, 2013:12).

Teori kebutuhan bertingkat Abraham Maslow merupakan mazhab ketiga dalam ilmu psikologi. Teori tersebut masuk dalam psikologi humanistik. Menurut Goble (1987: 31), psikologi humanistik melihat proses pertumbuhan dan perkembangan pribadi seseorang menuju tingkat yang lebih baik, menekankan uniknya seseorang, dan mempertimbangkan potensi-potensinya.

Pendapat yang sama dikemukakan Maslow Maslow berpendapat bahwa kebutuhan manusia sebagai pendorong (motivator) membentuk sebuah hierarki atau jenjang peringkat. Kebahagiaan manusia dapat dilihat ketika ia bisa mapan dalam menjalani jenjang-jenjang kehidupannya (Budiantoro dan Mardianto, 2016: 48). Tingkah laku manusia ditentukan oleh keinginan individu untuk mencapai tujuan kehidupan yang 
memuaskan dan membahagiakan bagi diri sendiri. (Minderop, 2011: 49).

Teori kebutuhan bertingkat dirumuskan sesuai dengan fakta dan pengalaman klinis. Teori tersebut tersusun mulai dari kebutuhan: fisiologis, rasa aman, cinta dan memiliki, harga diri, dan aktualisasi diri. (Maslow, 1994: 43). Kebutuhan-kebutuhan tersebut dapat dicapai satu per satu. Artinya jika pada kebutuhan tingkat rendah belum dapat terpenuhi maka kebutuhan tingkat selanjutnya juga tidak dapat terpenuhi.

Karya sastra tidak akan lepas adanya makna atau pesan yang dituliskan secara tersirat oleh penulis kepada pembaca. Pesan-pesan itu tercermin oleh nilai-nilai pendidikan karakter yang dimiliki para tokoh dalam cerita.

Novel Mata di Tanah Melus menceritakan anak dua belas tahun dengan karakter yang kuat. Tokoh utama harus menghadapi berbagai permasalahan. Cerita dalam novel tersebut dapat memberi pembelajaran kepada siswa SMP untuk meneladani nilai pendidikan karakter yang terkandung dalam novel tersebut. Sejalan dengan Samani dan Hariyanto (2012: 43), berpendapat bahwa karakter merupakan nilai dasar yang membangun pribadi seseorang, terbentuk baik karena pengaruh hereditas maupun pengaruh lingkungan yang membedakannya dengan orang lain, serta diwujudkan dalam sikap dan perilakunya dalam kehidupan sehari-hari. Hidayatullah (2010: 16) menambah pernyataan yaitu berdasar kenyataan dalam masyarakat menunjukkan adanya perubahan-perubahan yang melekat pada diri seseorang. Pendidikan memiliki peran penting dalam pembentukan karakter.

Novel Mata di Tanah Melus dapat dijadikan sebagai materi pembelajaran sastra di SMP karena materi novel yang tidak berat dan mudah dipahami oleh siswa SMP. Materi novel dapat memberikan pengalaman kepada pembaca cara untuk beradaptasi dengan lingkungan baru. Novel yang mengangkat cerita dengan keberagaman dapat membuat siswa belajar arti toleransi melalui pembelajaran sastra. Hal ini sesuai dengan kompetensi dasar kurikulum 2013 untuk kelas VIII semester 2.

\section{METODE PENELITIAN}

Penelitian terhadap novel Mata di Tanah Melus karya Okky Madasari merupakan penelitian deskriptif kualitatif dengan menggunakan metode analisis isi (content analysis). Pendekatan yang dipilih yaitu psikologi sastra untuk mengkaji aspek kejiwaan tokoh utama dalam novel. Data dalam penelitian ini yaitu hasil catatan kutipan-kutipan peristiwa dan perilaku tokoh dalam novel Mata di Tanah Melus karya Okky Madasari sesuai dengan rumusan masalah penelitian ini. Sumber datanya adalah novel Mata di Tanah Melus karya Okky Madasari yang diterbitkan Gramedia Pustaka Utama dan infoman.

Teknik pengumpulan data yang digunakan yaitu analisis dokumen dan wawancara. Teknik analisis data pada penelitian ini menggunakan model analisis interaktif. Validasi data yang digunakan yaitu triangulasi sumber data.

\section{HASIL DAN PEMBAHASAN}

\section{Struktur Novel Mata di Tanah Melus Karya Okky Madasari}

Novel Mata di Tanah Melus menceritakan pengalaman anak perempuan yang tersesat saat liburan ke Belu, NTT. Tema dalam novel ini yaitu sejarah suku asli Pulau Belu. Hal tersebut dikarenakan novel ini menggambarkan kehidupan suku Melus, suku yang menjadi bagian sejarah dari Belu. Tema lainnya yang menjadi tema minor dalam novel ini adalah adat istiadat, sistem kepercayaan, dan gaya hidup suku Melus.

Tokoh-tokoh dalam novel dibagi atas tokoh utama dan tokoh tambahan. Tokoh utamanya yaitu Matara. Tokoh tambahan yang dominan mendukung cerita dalam novel yaitu Ibu, Tania dan Ibunya, Paman Tania, Reinar, para suku Melus, Ratu kupu-kupu, Bei Nai, para pemburu

BASASTRA Jurnal Bahasa, Sastra, dan Pengajarannya

Volume 8 Nomor 1, April 2020, P-ISSN 2302-6405, E-ISSN 2714-9765 
buaya, dan para ilmuwan. Beberapa tokoh tambahan tidak dijelaskan secara lengkap gambaran fisik maupun psikologisnya.

Alur cerita dalam novel ini menunjukkan pergerakan maju. Hal tersebut ditandai adanya fase-fase eksposisi, inciting moment, rising action, complication, climax, falling action, denouement. Latar novel Mata di Tanah Melus terdapat tiga jenis, yaitu latar tempat, waktu, dan sosial budaya. Latar tempat terjadinya novel yaitu di Belu dan waktu terjadinya diperkiraan tahun 2017. Latar sosial yang ditampilkan dalam cerita yaitu kehidupan suku Melus yang terasing dari dunia luar.

Penelitian ini relevan dengan penelitian sebelumnya yang dilakukan oleh Hikma (2015) dengan judul Aspek Psikologis Tokoh Utama dalam Novel Sepatu Dahlan Karya Khrisna Pabichara (Kajian Psikologi Humanistik Abraham Maslow). Penelitian ini mengkaji aspek kejiwaan tokoh bernama Dahlan menggunakan teori kebutuhan bertingkat Abraham Maslow.

Simpulan dari penelitian ini dinyatakan bahwa tokoh Dahlan digambarkan sebagai pribadi yang inspiratif. Karakternya yang dewasa, mandiri, berwawasan terbuka, menghargai diri sendiri dan orang lain, serta tidak mudah menyerah pada setiap permasalahan-permasalahan sehingga ia mampu memenuhi kebutuhan-kebutuhan dasarnya.

Penelitian ini direlevansikan dengan pembelajaran yang menekan pada pendidikan karakter yang sesuai dengan tujuan. Persamaan penelitian Hikma dengan penelitian ini terletak pada teori psikologi sastra yang digunakan yaitu teori psikologi humanistik Abraham Maslow untuk mengkaji aspek kejiwaan tokoh. Perbedaannya terletak pada objek kajian dan relevansi hasil penelitian dengan pembelajaran.

\section{Aspek Kejiwaan Tokoh Utama dalam Novel Mata di Tanah Melus Karya Okky Madasari Berdasarkan Teori Kebutuhan Bertingkat Abraham Maslow}

Aspek kejiwaan tokoh utama ditinjau dari perilaku-perilakunya yang termotivasi untuk memenuhi kebutuhan hidup. Maslow (dalam Goble, 1987: 7177) merumuskannya sebagai sebagai teori kebutuhan bertingkat. Kebutuhan tersebut yaitu (a) kebutuhan fisiologis, (b) kebutuhan rasa aman, (c) kebutuhan dicintai dan memiliki-dimiliki, (d) kebutuhan penghargaan, (e) kebutuhan aktualisasi diri.

Kebutuhan fisiologis merupakan kebutuhan paling dasar yang harus dipenuhi manusia. Kebutuhan tersebut meliputi kebutuhan akan makan, minum, tempat tinggal, tidur, bernapas, kebutuhan biologis. Matara sudah memenuhi kebutuhan fisiologis dengan baik. Kebutuhan makan, minum, beristirahat, tempat tinggal sudah didapatkan karena Matara tinggal di lingkungan yang sudah mencukupi kebutuhan fisiologis. Perilaku yang menunjukkan pemenuhan kebutuhan fisiologis berupa makan digambarkan pada kutipan-kutipan berikut.

Aku menggendong tas punggungku yang berisi buku-buku, boneka beruangku, dan berbagai makanan yang aku beli di Jakarta. Sengaja kubawa semua yang kubutuhkan, karena belum tentu semua bisa didapatkan di tempat yang kami datangi. (Madasari, 2018:28).

Aha, aku tiba-tiba ingat selalu ada bekal makanan di tasku. Jajanan kesukaanku yang kubeli di Jakarta. Kami berdua segera memakan semuanya: roti, keripik, cokelat. (Madasari, 2018:73).

Kutipan di atas menunjukkan bahwa tokoh Matara melakukan usaha pemenuhan kebutuhan makan. Hal tersebut digambarkan oleh perilakunya membawa bekal makanan saat liburan. Matara sudah 
menyadari pentingnya makan dan minum untuk bertahan hidup sehingga ia melakukan usaha untuk mengantisipasi kelaparan. Secara sadar Matara sudah mampu memenuhi kebutuhan fisiologisnya sendiri didukung lingkungan yang mampu menyediakan kebutuhan tersebut.

Kebutuhan Matara akan tempat tinggal juga sudah terpenuhi dengan baik. Matara hidup bersama ayah dan ibunya di Jakarta menandakan terpenuhinya kebutuhan akan tempat tinggalnya. Ketika berlibur di Belu, Matara dan ibunya mampu menginap di hotel. Kebutuhan tempat tinggal Matara mampu dipenuhi dengan baik oleh orang tuanya. Berikut kutipan terpenuhinya kebutuhan tempat tinggal Matara.

"Rumahmu di mana, Tania?"

"Di sana... jauh," katanya sambil menunjuk ke arah selatan.

"Kamu?" tanyanya

"Kan di Jakarta," jawabku.

"Maksudku, di sini tinggal di mana?"

"Ooo... di hotel. Hotel Matahari." (Madasari, 2018:47).

Kebutuhan makan, minum, dan tempat tinggal sudah terpenuhi. Kebutuhan lain yaitu beristirahat atau tidur Matara cukup terpenuhi. Matara tidak mempunyai penyakit susah tidur. Hal tersebut berarti kebutuhan tidur Matara terpenuhi tetapi ia mengalami gangguan tidur saat liburan ke Belu. Ketika liburan, ia mengalami mimpi buruk tentang sapi sehingga kebutuhan tidur Matara terganggu.

Apalagi aku masih sangat mengantuk karena semalam tak nyenyak, bahkan bisa dibilang aku sama sekali tak tidur sejak mimpi buruk itu. (Madasari, 2018: 40).

Kebutuhan fisiologis Matara dalam novel Mata di Tanah Melus dapat disimpulkan sudah terpenuhi dengan baik. Lingkungan tempat tinggal yang layak sangat mendukung terpenuhinya kebutuhan fisiologis Matara.
Kebutuhan rasa aman merupakan kebutuhan perlindungan diri baik secara fisik maupun psikologis. Tokoh Matara belum mampu memenuhi kebutuhan rasa aman secara psikologis. Ia masih merasakan ketakutan dan cemas meskipun lingkungan sekitar tidak memberinya ancaman. Tidak terpenuhinya kebutuhan rasa aman secara psikologis Matara digambarkan pada kutipan berikut.

Aku menangis. Sungguh aku tak mau lagi mimpi sapi-sapi itu. Sapi-sapi itu membuatku ketakutan bahkan membuatku kini tak lagi memejamkan mata. (Madasari, 2018:51).

Sekarang aku kembali menangis. Kata-kata yang awalnya hanya kugunakan untuk meluluhkan hati Atok itu kini malah membuatku ketakutan sendiri. Bagaimana jika benar Mama diapa-apakan oleh orangorang itu? Bagaimana jika mereka membunuh Mama? Aku semakin tersedu-sedu. (Madasari, 2018:117).

Perasaan takut dan cemas Matara digambarkan melalui kutipan di atas. Perasaan takut dan cemas disebabkan ia harus terpisah dengan ibunya. Matara menjumpai orang yang baru dengan adat dan kebiasaan baru sehingga membuatnya merasa terancam. Terlebih dengan kondisi sosial suku Melus yang antipati terhadap orang asing.

Secara fisik, kebutuhan rasa aman Matara sudah terpenuhinya. Hal itu ditunjukkan dengan adanya sosok ibu yang melindunginya. Kenyataan bahwa suku Melus tidak akan membunuh anak-anak menunjukkan bahwa Matara berada di kondisi yang aman. Kutipan berikut menggambarkan perlindungan fisik yang diperoleh Matara.

Sementara aku merambat pelan-pelan, dua tangan ikut jadi topangan, Mama terus saja berseru. "Hati-hati! Pelanpelan!" (Madasari, 2018:60).

"Tak usah takut." kata perempuan itu dengan terbata-bata. Tampaknya ia 
tak terlalu bisa berbahasa Indonesia. "Ema Naim minta kami menjagamu. (Madasari, 2018:83).

Kutipan di atas menjelaskan terpenuhinya kebutuhan rasa aman secara fisik Matara. Sosok ibu dan para suku Melus selalu menjaga Matara dengan baik meskipun rasa takut dan cemas mendominasi perasaan Matara. Perasaan tidak aman yang dirasakan Matara menjadikan simpulan bahwa kebutuhan rasa aman belum terpenuhi. Faktor penyebabnya yaitu kebiasaan, adat, orangorang baru membuat Matara merasa tidak nyaman dan takut.

Kebutuhan Dicintai dan MemilikiDimiliki menunjukkan bahwa manusia adalah mahluk sosial. Kasih sayang dan cinta membuat manusia merasa lebih hidup dan manusiawi. Kebutuhan kasih sayang atau cinta yang dirasakan Matara dalam novel Mata di Tanah Melus ia dapatkan dari keluarga. Perilaku yang menunjukkan hal tersebut yaitu ibunya yang peduli dengan pendidikan Matara dan ayahnya yang berusaha menemani kegiatan Matara seperti pada kutipan berikut.

Ia masih selalu bertanya padaku apa saja yang aku lakukan dan dipelajari di sekolah. (Madasari, 2018:17).

Setiap hari Papa berangkat kerja jam satu siang, lalu pulang jam satu dini hari. Di pagi hari, ia bangun, menemani aku sarapan, mengantarkan aku ke sekolah, lalu kembali pulang dan melanjutkan tidurnya sampai siang. (Madasari, 2018:20).

Kasih sayang dari kedua orang tuanya tidak membuat Matara merasa kebutuhan tersebut tercukupi. Matara merasa tidak sepenuhnya dicintai hanya dengan perilaku-perilaku di atas. Matara masih banyak mengeluhkan sikap ibu dan ayah yang kurang perhatian dengan Matara. Hal tersebut memperlihatkan kebutuhan akan rasa dicintai Matara masih kurang terpenuhi. Kutipan berikut menunjukkan Matara yang merasa kurang disayangi.

Mama lebih suka menyendiri di ruang kerjanya untuk menulis cerita, setiap hari, sepanjang hari. Sementara aku mendengarkan cerita dari temboktembok kamarku, boneka-bonekaku, dari pikiran-pikiranku sendiri. (Madasari, 2018:13).

Bentuk kasih sayang lainnya yang diterima Matara yaitu diterima dalam kelompok. Ketika tersesat di kampung Melus, Matara bisa diterima oleh orangorang Melus setelah upacara pembersihan jiwa. Setelah upacara tersebut, orang Melus dapat berinteraksi dan menyambut baik Matara. Hal tersebut ditunjukkan oleh kutipan berikut.

Semua orang seperti sudah mengenalku. Mereka tersenyum, melambaikan tangan, juga memanggilku. Awalnya aku heran, tapi kemudian aku ingat semua orang Melus datang di upacara itu. Kini semuanya tampak bersahabat, tak ada yang melihatku dengan tatapan curiga, apalagi penuh kemarahan. (Madasari, 2018:96).

Penerimaan dalam kelompok merupakan bentuk pemenuhan kasih sayang. Penerimaan ditunjukkan dengan perilaku Matara yang bermain dengan anak-anak suku Melus. Penerimaan Matara di suku Melus tidak sepenuhnya baik, mengingat suku Melus yang selalu curiga terhadap orang asing. Ada waktu ketika mereka kembali curiga terhadap Matara. Sikap Matara pun sama demikian. Ia juga tidak bisa sepenuhnya menerima suku Melus karena mereka dianggap sebagai orang asing.

Kebutuhan Penghargaan dapat dibedakan menjadi harga diri dan penghargaan dari orang lain. Kebutuhan penghargaan Matara belum cukup terpenuhi. Penghargaan dari orang lain berupa pengakuan, status belum didapatkan secara baik oleh Matara. 
Matara merupakan orang baru ketika datang ke suku Melus, ia ingin diakui sebagai orang Jakarta seperti kenyataannya tetapi suku Melus tidak mengakui itu. Suku Melus menuduh Matara sebagai kiriman orang Bunag yang jahat. Berikut kutipan yang menggambarkan kebutuhan pengakuan tersebut.

"Kemarin kamu bilang ada mamamu! Mamamu bersama orang yang bawa pistol kemarin, kan? Mereka orang Bunag! Mamamu orang Bunag! Kamu orang Bunag!

"Bukan! Aku bukan orang Bunag!" (Madasari, 2018:115).

Suku Melus yang selalu menganggap Matara sebagai suruhan dari orang Bunag menandakan bahwa belum tercukupinya kebutuhan penghargaan berupa pengakuan. Suku Melus juga menolak status Matara sebagai orang Jakarta. Faktor utama belum terpenuhinya kebutuhan penghargaan Matara yakni karena Matara masih proses memenuhi kebutuhan akan rasa aman.

Kebutuhan aktualisasi diri adalah kebutuhan puncak bagi manusia. Kebutuhan ini akan muncul jika empat kebutuhan sebelumnya sudah tercukupi dengan baik. Aktualisasi diri dicirikan ketika manusia sudah mencapai tahap kematangan diri dan hidupnya sudah dalam keadaan statis. Berdasarkan hasil analisis, Matara belum mencapai tahap aktualisasi diri. Di usia dua belas tahun ini, Matara masih dalam proses pencarian jati diri. Ia masih dalam tahap memenuhi kebutuhan rasa aman, kebutuhan dicintai, kebutuhan penghargaan, dan menuju penemuan jati diri. Semua perilaku yang dilakukan Matara bertujuan untuk memenuhi kebutuhan-kebutuhan tersebut.

Penelitian ini relevan dengan penelitian sebelumnya yang dilakukan oleh Purika, Andayani, Sumarlam (2016) yang berjudul Aspek Kejiwaan Tokoh dan Nilai Pendidikan Karakter Novel The Chronicle of Kartini Karya Wiwid Prasetyo serta
Relevansinya dengan Bahan Pembelajaran Bahasa Indonesia di SMA. Persamaan penelitian Purika, Andayani, dan Sumarlam terletak pada pendekatan penelitian dan teori yang digunakan. Kedua penelitian ini menggunakan pendekatan psikologi sastra dan teori yang digunakan yaitu teori kebutuhan bertingkat Abraham Maslow. Perbedaanya terletak pada objek kajian dan kajian tentang relevansi. Penelitian ini mengkaji novel karya Wiwid Prasetyo dan mengkaji relevansinya dengan pembelajaran bahasa Indonesia di SMA.

\section{Nilai Pendidikan Karakter dalam Novel Mata di Tanah Melus}

Karya sastra mengandung makna yang luas dan memiliki nilai-nilai yang terkandung di dalamnya. Nilai-nilai tersebut dapat menjadi sarana pendidikan bagi para pembaca. Hal tersebut menjadikan pembelajaran sastra merupakan usaha bentuk internalisasi nilainilai pendidikan karakter. Sastra dalam pendidikan anak berperan untuk mengembangkan aspek kognitif, afektif, psikomotorik, mengembangkan kepribadian dan pribadi sosial (Wibowo, 2013:19-20).

Berdasarkan penelitian ditemukan nilai-nilai pendidikan karakter dalam novel Mata di Tanah Melus, nilai-nilai tersebut antara lain: (1) rasa ingin tahu, (2) toleransi, (3) bersahabat atau komunikasi, (4) gemar membaca, (5) religius, (6) peduli lingkungan. Keenam nilai pendidikan karakter yang paling dominan tercermin dalam karakter Matara yaitu karakter rasa ingin tahu.

Karakter Matara merupakan anak yang penuh dengan rasa ingin tahu terlihat saat perjalanannya berlibur ke Belu. Setiap hal yang ia lihat berbeda dengan kebiasaan maka ia akan menanyakannya kepada orang di sekitar. Hal tersebut terjadi saat Matara terheran banyak hewan-hewan ternak berkeliaran bebas di jalan. Guna memenuhi rasa ingin tahunya maka Matara menanyakan hal tersebut kepada ibunya

BASASTRA Jurnal Bahasa, Sastra, dan Pengajarannya 
dan sopir mobil yang ditumpanginya. Matara juga anak yang senang mengeksplorasi keadaan sekitar yang belum pernah ia datangi. Perilaku-perilaku tersebut menunjukkan nilai pendidikan karakter rasa ingin tahu.

Penelitian yang relevan dengan penelitian ini yaitu penelitian yang dilakukan oleh Kurniawati pada tahun 2014. Penelitian tersebut berjudul Nilai Pendidikan Karakter Novel Burlian Karya Tere Liye dan Skenario Pembelajarannya di SMA. Penelitian ini mengkaji nilai-nilai pendidikan yang terdapat dalam novel Burlian. Nilai pendidikan karakter yang terdapat dalam novel tersebut yaitu religius gemar membaca, disiplin, cinta tanah air, peduli sosial, peduli lingkungan, tanggung jawab, dan jujur. Penelitian tersebut memiliki kesamaan dengan penelitian dalam novel Mata di Tanah Melus Karya Okky Madasari, yakni membahas nilainilai pendidikan karakter. Perbedaannya terletak pada objek kajian penelitian dan relevansi hasil penelitiannya.

\section{Relevansi Hasil Penelitian Novel Mata di Tanah Melus dengan Pembelajaran Sastra di SMP}

Relevansi kajian ini dibuktikan adanya kompetensi dasar pada kurikulum 2013 yang menjadikan novel sebagai materi pembelajaran . Kompetensi dasar tersebut yaitu KD 3. 11 mengidentifikasi teks tanggapan tentang novel. Selain itu, kurikulum 2013 sangat menekankan pada nilai pendidikan karakter dalam pembelajaran yang diperkuat dengan pendapat para guru. Guru menerapkan nilai-nilai pendidikan karakter kepada siswa di setiap pembelajaran. Pada pembelajaran sastra novel dapat menjadi media yang baik untuk menanamkan pendidikan karakter.

Novel Mata di Tanah Melus memiliki relevansi sebagai materi pembelajaran sastra di SMP dinyatakan melalui wawancara dengan guru-guru bahasa Indonesia SMP dan psikolog. Narasumber sepakat menyatakan bahwa hasil penelitian novel tersebut layak dijadikan materi pembelajaran sastra di SMP. Berdasarkan instrumen penilaian buku pengayaan kepribadian yang dikembangkan Pusat Kurikulum dan Perbukuan, novel Mata di Tanah Melus sangat layak dijadikan materi pembelajaran. Dilihat dari aspek isi, bahasa, penyajian, dan grafis novel ini sudah memenuhi standar kelayakan. Aspek isi dari novel ini sudah sesuai dengan tujuan pendididkan nasional yang menginginkan peserta didik berketuhanan dan berkarakter. Hal tersebut ditunjukkan adanya nilai-nilai pendidikan karakter religius, gemar membaca, rasa ingin tahu, dan toleransi. Bahasa yang komunikatif dalam novel mudah dipahami oleh pembaca tanpa menimbulkan multitafsir. Tata tulis yang sesuai kaidah kebahasaan yang benar juga membantu peserta didik mengenalkan bahasa yang baik dan benar. Aspek penyajian yang memperhatikan unsur instrinsik sejalan dengan kompetensi dasar menelaah unsur-unsur novel.

Penelitian yang relevan dengan penelitian ini yaitu penelitian yang dilakukan oleh Andi Pratiwi, Heri Suwigyo, dan Ida Lestari pada tahun 2012. Penelitian tersebut berjudul Nilai-nilai Akhlak Mulia dalam Kumpulan Cerpen Orang-Orang Tercinta dan Setegar Kupukupu Tak Bersayap dan Saran Implementasinya untuk Pendidikan Karakter Siswa SMP Kelas VIII Melalui Pembelajaran Apresiasi Sastra. Penelitian tersebut memiliki kesamaan dengan penelitian dalam novel Mata di Tanah Melus Karya Okky Madasari, yakni membahas nilai-nilai pendidikan karakter dalam novel dan relevansinya sebagai bahan ajar di sekolah di kelas VIII SMP.

\section{SIMPULAN}

Hasil penelitian dan pembahasan kajian psikologi sastra novel Mata di Tanah Melus karya Okky Madasari dapat disimpulkan sebagai berikut. Pertama, novel ini mengangkat tema tentang sejarah suku di Pulau Belu yang diceritakan 
melalui pengalaman tokoh utama. Tokoh utama dalam novel yaitu Matara, anak perempuan berumur dua belas tahun. secara psikologis, Matara digambarkan sebagai seorang anak-anak yang penuh rasa ingin tahu dan berjiwa petualang. Pengalaman Matara didukung oleh tokoh tambahan yaitu Ibu Matara, Atok, para suku Melus, Ratu Kupu-kupu, Bei Nai, para pemburu buaya, dan para peneliti. Novel Mata di Tanah Melus memiliki pergerakan alur maju dimulai dari eksposisi, inciting moment, rising action, complication, climax, penyelesaian. Latar tempat terjadinya novel yaitu di Belu dan waktu terjadinya diperkiraan tahun 2017. Latar sosial yang ditampilkan dalam cerita yaitu kehidupan suku Melus yang terasing dari dunia luar.

Kedua, aspek kejiwaan Matara sebagai tokoh utama dilihat dari usahanya untuk memenuhi kebutuhan bertingkat. Hasil dari penelitian terhadap kejiwaan Matara menunjukkan bahwa Matara masih dalam tahap pemenuhan kebutuhan akan rasa aman. Kebutuhan fisiologis yang berada pada tingkat pertama sudah terpenuhi dengan baik. Kebutuhan tingkat selanjutnya yakni kebutuhan akan rasa aman yang belum terpenuhi. Secara fisik, Matara sudah mendapat perlindungan dari lingkungan sekitar tetapi tidak secara psikologis belum dapat terpenuhi. Rasa cemas dan takut yang Matara rasakan membuat ia belum mampu mencukup kebutuhan rasa aman. Kebutuhan rasa dicintai dan dimiliki-memiliki belum terpenuhi dengan baik meskipun ada beberapa perilaku yang menunjukkan pemenuhan kebutuhan ini. Kebutuhan tingkat lanjutnya yakni kebutuhan penghargaan belum tercukupi karena Matara belum dapat mandiri dan pengakuan dari orang lain. Kebutuhan aktualisasi diri yang berada di tingkat paling atas belum dapat terpenuhi karena Matara masih berusaha untuk memenuhi kebutuhan pada tingkat rendah yang belum terpenuhi.

Ketiga, nilai-nilai tersebut yakni (1) rasa ingin tahu, (2) toleransi, (3) bersahabat atau komunikatif, (4) gemar membaca, (5) religius, (6) peduli lingkungan, (7) tanggung jawab, (8) kerja keras. Nilai pendidikan paling dominan dalam novel yaitu nilai pendidikan karakter rasa ingin tahu. Karakter tersebut tercermin dari perilaku tokoh Matara.

Keempat, novel Mata di Tanah Melus dapat dimanfaatkan untuk materi pembelajaran di SMP kelas VIII semester II. Hal tersebut dibuktikan adanya Kompetensi Dasar pada Kurikulum 2013 yang membahas tentang struktur novel. Selain itu, novel ini dinilai layak untuk digunakan dalam pembelajaran mengacu pada instrumen penilaian buku nonteks pelajaran yang dikembangkan oleh Pusat Kurikulum dan Perbukuan. Penilaian dilakukan untuk melihat dari aspek isi dan bahasa. Penilaian tersebut juga diperkuat dengan pendapat guru-guru, penulis novel, dan psikolog yang didapat dari hasil wawancara.

Saran peneliti kepada guru bahasa dan sastra Indonesia hendaknya dapat mengenalkan sastra kepada siswa sejak dini melalui pembelajaran maupun kegiatan literasi. Pemilihan novel untuk materi pembelajaran diharapkan dapat disesuaikan dengan perkembangan psikologis siswa. Siswa juga hendaknya meningkatkan kegiatan literasi membaca karya sastra. Kegiatan tersebut tidak hanya sekadar membaca tetapi siswa juga perlu meresapi makna dan pesan-pesan yang disampaikan penulis melalui hasil karyanya.

\section{REFERENSI}

Budiantoro, W. \& Mardianto, W. (2016). Aplikasi Teori Psikologi Sastra. Purwokerto: Penerbit Kaldera. $\begin{array}{rrr}\text { Endaswara, S. } & \text { (2013). } & \text { Metodologi } \\ \text { Penelitian } & \text { Sastra; } & \text { Epistemologi, } \\ \text { Model, } & \text { Teori, } & \text { Aplikasi. }\end{array}$ 
Yogyakarta: CAPS (Center for Academis Publishing Service).

Emzir dan Rohman, S. (2015). Teori dan Pengajaran Sastra. Jakarta: PT Raja Grafindo Persada.

Goble, F. G. (1987). Mazhab Ketiga: Psikologi Humanistik Abraham Maslow. Yogyakarta: Penerbit Kanisius.

Hidayatullah, M. F. (2010). Guru Sejati: Membangun Insan Berkarakter Kuat dan Cerdas. Surakarta: Yuma Pustaka.

Hikma, N. (2015). Aspek Psikologis Tokoh Utama dalam Novel Sepatu Dahlan Karya Khrisna Pabichara (Kajian Psikologi Humanistik Abraham Maslow). Jurnal Humanika, 3 (15), 1-15.

Kurniawati, D. E. (2014). Nilai Pendidikan Karakter Novel Burlian Karya Tere Liye dan Skenario Pembelajarannya di SMA. Surya Bahtera, 2 (14), 1-6.

Madasari, O. (2018). Mata di Tanah Melus. Jakarta: Gramedia Pustaka Utama.

Maslow, A. H. (1994). Teori Motivasi dan Kepribadian. Jakarta: PT PBP.

Minderop, A. (2010). Psikologi Sastra: Karya Sastra, Teori, Metode, dan Contoh Kasus: Jakarta:Yayasan Pustaka Obor Indonesia.

Pratiwi, Y. A, Suwigyo, H, \& Lestari, I. (2012). Nilai-nilai Akhlak Mulia dalam Kumpulan Cerpen OrangOrang Tercinta dan Setegar Kupukupu Tak Bersayap dan Saran Implementasinya untuk Pendidikan Karakter Siswa SMP Kelas VIII Melalui Pembelajaran Apresiasi Sastra. Jurnal Bahasa dan Sastra Indonesia Universitas Negeri Malang, 1 (2).

Purika, D. A., Andayani, \& Sumarlam. (2016). Aspek Kejiwaan Tokoh dan Nilai Pendidikan Karakter Novel The Chronicle of Kartini Karya Wiwid Prasetyo serta Relevansinya dengan Bahan
Pembelajaran Bahasa Indonesia di SMA. Jurnal S2 Pendidikan Bahasa Indonesia, 1 (1), 66-79.

Samani, M. \& Heriyanto. (2013). Pendidikan Karakter. Bandung: PT Remaja Rosadakarya.

Staton, R. (2012). Teori Fiksi. Yogyakarta: Pustaka Pelajar

Suaka, N. (2014). Analisis Sastra: Teori dan Aplikasi. Yogyakarta: Penerbit Ombak.

Sugiyono. (2013). Memahami Penelitian Kualitatif. Bandung: Alfabeta.

Wibowo, A. (2013). Pendidikan Karakter di Perguruan Tinggi. Yogyakarta: Pustaka Pelajar. 